\title{
Electrocardiographic patterns of exercise-induced ventricular arrhythmias in patients with and without coronary artery disease
}

\author{
Koroner arter hastalığı olan ve olmayan hastalarda egzersize bağlı ventriküler aritminin \\ elektrokardiyografik özellikleri
}

Özgül Malçok Gürel ${ }^{1}$, Özcan Özeke², Fırat Özcan², Çağatay Ertan², Zafer Büyükterzi², Tümer Erdem Güler², Aytun Canga ${ }^{2}$, Veli Kaya², Mehmet Fatih Özlü ${ }^{4}$, Dursun Aras $^{2}$, Ahmet Duran Demir ${ }^{3}$

\begin{abstract}
Objectives: This study was carried out to compare the electrocardiographic characteristics of exercise-induced ventricular arrhythmias (EIVA) in patients with and without coronary artery disease (CAD).

Methods: The exercise tests of patients who were diagnosed to have EIVA and also underwent coronary angiography were analyzed retrospectively. The electrocardiographic patterns of EIVA in patients with and without CAD were compared.
\end{abstract}

Results: The most common EIVA was premature ventricular contractions (PVCs) with left bundle-branch block (LBBB) pattern and inferior axis in both groups $(63 \%$ in normal coronary artery (NCA) group and 59\% in CAD group). PVCs with right bundle-branch block (RBBB) pattern and superior axis (33\% vs. $17 \%, p=0.001)$ and the presence of multifocal PVC were found to be more frequent in CAD group (23\% vs. $7 \%, p<0.001)$. Also, the timing of the exercise induced PVCs (during exercise, recovery or both) did not differ between the groups.

Conclusion: The present study revealed that the most common EIVA was PVCs with LBBB pattern and inferior axis. Also, multifocal PVCs and the PVCs in RBBB pattern with superior axis were more common in CAD patients. J Clin Exp Invest 2014; 5 (1): 40-44

Key words: Coronary artery disease, exercise test, ventricular arrhythmias

\section{INTRODUCTION}

Ventricular arrhythmias are common findings during clinical exercise testing [1]. Exercise-induced premature ventricular contractions (EIPVCs) may

\section{ÖZET}

Amaç: Bu çalışma, koroner arter hastalığı $(\mathrm{KAH})$ olan ve olmayan hastalarda egzersize bağlı ventriküler aritmi (EBVA) ve elektrokardiyografik özelliklerini karşılaştırmak amacıyla yapılmıştır.

Yöntemler: Egzersiz testinde EBVA tespit edilen ve aynı zamanda koroner anjiyografi uygulanan hastalar geriye dönük olarak incelendi. KAH olan ve olmayan hastaların EBVA'larının elektrokardiyografik özellikleri incelendi.

Bulgular: Her iki hasta grubunda da en sık görülen EBVA, sol dal bloğu (LBBB) ve inferiyor eksen içeren erken ventriküler atımlar (EVA) idi (Normal koroner arter (NKA) grubunda \% 63 ve KAH grubunda \% 59). Sağ dal bloğu (RBBB) ve superiyor eksen şeklindeki EVA (\%33 vs. $\% 17, p=0,001)$ ve multifokal EVA, KAH grubunda daha sık bulundu ( $\% 23$ vs. \% 7, p<0,001). Ayrıca, egzersizin tetiklediği EVA zamanlamasında (egzersiz sırasında, dinlenme dönemi ya da her ikisinde) gruplar arasında fark saptanmadı.

Sonuç: Bu çalışma, en sık EBVA'nın LBBB ve inferiyor eksenli EVA'lar olduğunu ortaya koydu. Ayrıca, multifokal EVA'lar ve RBBB ve süperiyor eksen şeklindeki EVA'lar $\mathrm{KAH}$ hastalarında daha sık bulundu.

Anahtar kelimeler: Egzersiz testi, koroner arter hastalığı, ventriküler aritmi

be found in up to $30 \%$ of healthy subjects, in $60 \%$ of those with heart disease and in all patients who have experienced sustained ventricular tachycardia [2]. Although an association between the occurrence

${ }^{1}$ Department of Cardiology, Turgut Özal University, Ankara, Turkey

2 Department of Cardiology, Turkiye Yuksek intisas Hospital, Ankara, Turkey

${ }^{3}$ Department of Cardiology, Acibadem Hospital, Eskisehir, Turkey

${ }^{4}$ Department of Cardiology, Abant Izzet Baysal University, Bolu, Turkey

Correspondence: Özgül Malçok Gürel,

Dept. Cardiology, Turgut Özal University, Faculty of Medicine, Ankara, Turkey Email: ozgulmalcok@gmail.com

Received: 05.12.2013, Accepted: 04.02.2014

Copyright (C) JCEI / Journal of Clinical and Experimental Investigations 2014, All rights reserved 
of exercise-induced ventricular arrhythmias (EIVAs) and coronary artery disease (CAD) has been described, a consensus has not existed regarding the relation of EIVAs to CAD or to cardiovascular risk because of the conflicting results from the available studies [3-5]. Because arrhythmias are a part of acute coronary syndromes, it seems reasonable to expect this association during exercise. However, whereas some studies have suggested an association of EIVAs with exercise-induced ischemia $[6,7]$, other studies refute these results $[3,8,9]$.

Although exercise represents a well-known triggering factor of ventricular arrhythmias in patients with CAD, mainly because of the increase in sympathetic activity and release of catecholamines, it is unclear if the prognosis associated with EIVAs differ based on the presence of CAD, ischemic changes during exercise, and/or the presence of premature ventricular contractions (PVCs) at rest (i.e., an indicator of the arrhythmic substrate) $[1,10]$. Some morphologic characteristics of EIVAs have been shown to provide prognostic information [10]. In current study, we aimed to evaluate whether there is a relationship between the some EIVA morphologic patterns and the presence of CAD.

\section{METHODS}

From the archive of our institution, the exercise tests of 6446 patients were reviewed retrospectively for the presence of ventricular arrhythmia. The exercise tests of patients who underwent coronary angiography with the EIVAs were analyzed. Patients' demographic and clinical data were obtained from medical records. The exercise tests of patients with antiarrythmic drug use, heart failure, anemia, thyroid disorder, electrolyte imbalance and many artifacts on treadmill recordings were not included in the analysis.

Study population was divided into two groups: Group 1 included the patients without stenosis on coronary angiography (normal coronary artery (NCA) group) and group 2 consisted of patients with CAD (CAD group). Coronary artery disease was defined as a $>50 \%$ luminal stenosis of the left main coronary artery or a $>70 \%$ stenosis of any other major epicardial coronary arteries or major branches.

Exercise test of patients were performed on a treadmill device (Kardiosis Ltd. Co, Ankara, Turkey) according to the multistage Bruce protocol. During the procedure, all standart leads were monitored and recorded. EIVAs were defined as the frequent PVCs, sustained ventricular tachycardia (VT: lasting more than 30 seconds or requiring intervention) and non-sustained ventricular tachycardia (NSVT: 3 or more consecutive PVC and less than $30 \mathrm{~s}$ ). We coded the morphology of EIVAs as right bundle-branch block (RBBB) pattern (positive predominance in V1 and negative predominance in V6), left bundle-branch block (LBBB) pattern (negative predominance in $\mathrm{V} 1$ and positive predominance in V6), masquerading bundle branch block pattern (positive predominance in both V1 and V6) or undetermined pattern (negative predominance in both $\mathrm{V} 1$ and V6). The frontal plane axis was designated as inferior (1 to 180 degrees) or superior ( $>180$ to 0 degrees) [11].

The SPSS statistical software package (version 20.0; SPSS Inc, Chicago, III) was used to perform all statistical calculations. Continuous variables were expressed as mean $\pm \mathrm{SD}$. Categorical variables were expressed as numbers and percentages, and compared using the Chitest. Two group comparisons were performed using an unpaired ttest or nonparametric Mann-Whitney $U$ test according to normality test results. P-value less than 0.05 were defined statistically significant.

\section{RESULTS}

The patients' demographic and exercise related electrocardiographic morphological features are shown in the table. Of the 324 patients with EIVAs, 160 had angiographic evidence of CAD (Group 2) and the remaining 164 had no significant stenosis on coronary angiography (NCA group). The male/ female ratio was significantly higher in CAD group than the NCA group ( $89 \%$ vs. $61 \% p<0.001)$.

Sustained VT or NSVT ratios and patterns were found to be similar in CAD and NCA groups. The most common EIVA was found to be PVCs with LBBB pattern and inferior axis in both groups (63\% in NCA group and $59 \%$ in CAD group). PVCs with RBBB pattern and superior axis (33\% vs. $17 \%$, $p=0.001)$ and the presence of multifocal PVCs were seen more frequently in CAD group $(23 \%$ vs. $7 \%$, $p<0.001)$. The other forms of ventricular premature complexes were found to be similar in both groups. Also there was no significant difference between the groups with regard to the timing of EIPVCs (during exercise, recovery or both) (Table 1). 
Table 1. The demographic and exercise related electrocardiographic morphological features of the patients.

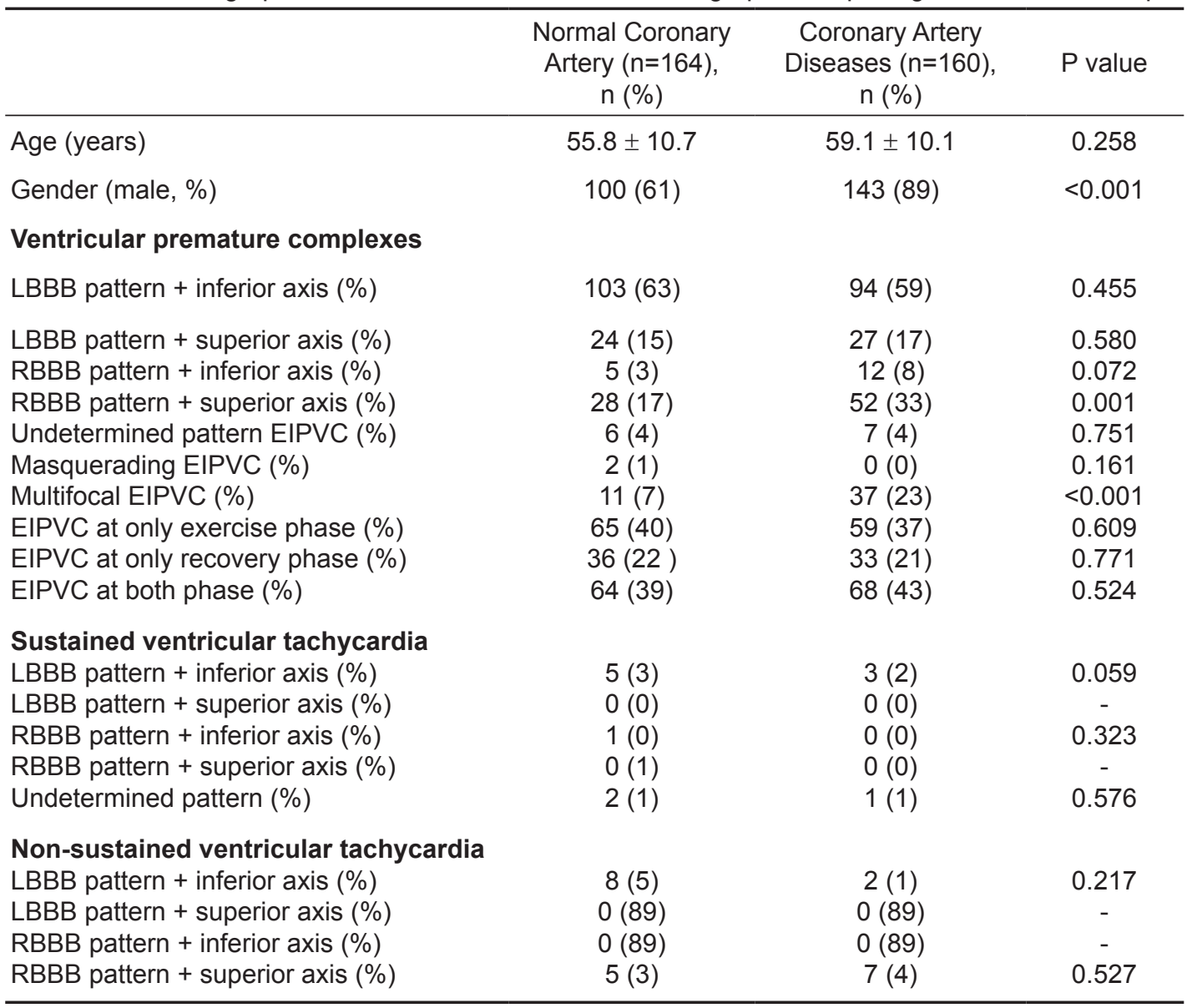

LBBB: Left bundle-branch block, RBBB: Right bundle-branch block, EIPVC: Exercise-induced premature ventricular contraction

\section{DISCUSSION}

The main findings of this study are; 1. Most common EIVAs were PVCs in LBBB form with inferior axis, 2. Multifocal PVCs and the PVCs in RBBB pattern with superior axis were more common in CAD patients.

Over the years, most cardiologists have largely ignored PVCs during exercise testing [12]. There is conflicting evidence about the relation of EIVAs to $\mathrm{CAD}$ or to cardiovascular risk in both healthy asymptomatic subjects [5, 13, 14] and CAD patients $[8,9,15]$. In the Framingham community cohort, EIPVCs were associated with increased mortality than had been previously reported [16]. Recently, two large, prospective studies of asymptomatic healthy individuals reported that frequent EIPVCs are associated with increased risk of cardiovascular mortality (>2.5 among men ) over a longer period of follow-up exceeding 20 years $[17,18]$.

Although patients with suspected CAD may have EIPVCs caused by the presence of an isch- emic substrate, the clinical correlates of EIPVCs in asymptomatic individuals without such a substrate are incompletely understood. The occurrence of ElVAs during exercise may be related to exercise induced myocardial ischemia or endothelial dysfunction, especially when combined with ST-segment depression [19, 20]. Trejo et al. found that EIVAs were related to the extent of CAD [21], whereas Schweikert et al. concluded that EIPVCs were associated with a greater likelihood of thallium perfusion defects, but not associated with angiographic presence and severity of CAD [22]. Rodriguez et al. speculated that the electrophysiological substrate of exercise induced ventricular tachycardia (EIVT) in CAD patients did not differ from the substrate of non-exercise-related VT and the re-entry was the most probable electrophysiological mechanism [23]. It seems reasonable to assume that the presence of EIVAs indicate a region of increased excitability and that their relationship to exercise suggests catecholamine sensitivity. But the studies provide no 
further insight into whether the EIVAs are due to reentry, to enhanced automaticity, or to after depolarizations [1]. As noted above, their presence is not linked to ischemia but is related in a linear fashion to increasing age. This suggests that a change in myocardial substrate over time might have been related to the increase in cardiovascular mortality associated with EIVAs [1]. According to several reports, in the absence of evidence of ischemia, EIPVCs have almost no power to predict CAD [24]. Beckerman et al. in their review [1] and studies [14] speculated that exercise-induced ST depression is not arrhythmogenic whereas exercise induced ST elevation is very arrhythmogenic and associated with a high risk, and concluded that exercise-induced ischemia does not affect the prognostic value of EIVAs. They do not advocate cardiac catheterization in patients with EIVAs but with otherwise absolutely normal exercise treadmill tests, and suggested that clinical decisions should be made on an individual basis [1].

In the present study, we found that the multifocal PVCs and the PVCs in RBBB pattern with superior axis were seen more frequently in CAD patients compared to NCA subjects. This finding is compatible with previous studies suggesting that the RBBBconfiguration arrhythmia, presumably originating from the left ventricle, is often associated with left ventricular disease, depressed ventricular function and greater mortality compared to LBBB pattern [10].

Idiopathic VT most commonly arises from the right ventricular outflow tract, and less often from the left ventricular outflow tract. Two subtypes of outflow tract VT have been described: repetitive monomorphic VT and paroxysmal EIVT [25, 26]. Milanes et al reported a higher prevalence of VT in patients with CAD compared to patients with NCAs. Of note, $80 \%$ of patients with EIVT had an abnormal ST response as well [27]. The exercise induced non-sustained ventricular tachycardia (EINVT) has been found not to be associated with complications during testing or with significantly increased cardiovascular mortality within 2 years after testing [28]. We could not detect any difference in morphological pattern of EIVT or EINVT between the groups.

The main limitations were the limited number of patients in our population, the retrospective design of our study and male predominance in our CAD population. Also the electrocardiographic patterns of EIVAs according to severity of CAD were not analyzed.

The present study revealed that the most common EIVA was PVCs in LBBB form with inferior axis and also showed that multifocal EIPVCs and the PVCs in RBBB pattern with superior axis were more common in CAD patients compared to NCA subjects. When evaluating the EIVAs, physicians should search diligently for underlying structural heart diseases, particularly CAD in adults, right ventricular dysplasia, congenital coronary anomalies, hypertrophic or dilated cardiomyopathy, myocarditis, and catecholaminergic polymorphic ventricular tachycardia in young patients [29]. Some electrocardiographic patterns may provide a clue for this differential diagnosis. Future investigators should examine how the morphology and exact quantification of EIVA affect prognosis.

\section{REFERENCES}

1. Beckerman J, Wu T, Jones S, Froelicher VF. Exercise test-induced arrhythmias. Prog Cardiovasc Dis 2005;47:285-305.

2. Candinas RA, Podrid PJ. Evaluation of cardiac arrhythmias by exercise testing. Herz 1990;15:21-27.

3. Weiner DA, Ryan TJ, McCabe $\mathrm{CH}$, et al. Prognostic importance of a clinical profile and exercise test in medically treated patients with coronary artery disease. J Am Coll Cardiol 1984;3:772-779.

4. Casella G, Pavesi PC, Sangiorgio P, et al. Exercise-induced ventricular arrhythmias in patients with healed myocardial infarction. Int J Cardiol 1993;40:229-235.

5. Busby MJ, Shefrin EA, Fleg JL. Prevalence and longterm significance of exercise-induced frequent or repetitive ventricular ectopic beats in apparently healthy volunteers. J Am Coll Cardiol 1989;14:1659-1665.

6. Fleg JL, Lakatta EG. Prevalence and prognosis of exercise-induced non-sustained ventricular tachycardia in apparently healthy volunteers. Am J Cardiol 1984;54:762-724.

7. Faris JV, McHenry PL, Jordan JW, Morris SN. Prevalence and reproducibility of exercise-induced ventricular arrhythmias during maximal exercise testing in normal men. Am J Cardiol 1976;37:617-622.

8. Sami M, Chaitman B, Fisher L, et al. Significance of exercise-induced ventricular arrhythmia in stable coronary artery disease: a coronary artery surgery study project. Am J Cardiol 1984;54:1182-1188.

9. Elhendy A, Chandrasekaran K, Gersh BJ, et al. Functional and prognostic significance of exercise-induced ventricular arrhythmias in patients with suspected coronary artery disease. Am J Cardiol 2002;90:95-100.

10. Eckart RE, Field ME, Hruczkowski TW, et al. Association of electrocardiographic morphology of exerciseinduced ventricular arrhythmia with mortality. Ann Intern Med 2008;149:451-60, W82.

11. Dixit S, Gerstenfeld EP, Callans DJ, Marchlinski FE. Electrocardiographic patterns of superior right ventricular outflow tract tachycardias: distinguishing septal and free-wall sites of origin. J Cardiovasc Electrophysiol 2003;14:1-7. 
12. Rasouli ML, Ellestad MH. Usefulness of ST depression in ventricular premature complexes to predict myocardial ischemia. Am J Cardiol 2001;87:891-4.

13. Partington S, Myers J, Cho S, et al. Prevalence and prognostic value of exercise-induced ventricular arrhythmias. Am Heart J 2003;145:139-146.

14. Beckerman J, Mathur A, Stahr S, et al. Exerciseinduced ventricular arrhythmias and cardiovascular death. Ann Noninvasive Electrocardiol 2005;10:47-52.

15. Califf RM, McKinnis RA, McNeer JF, et al. Prognostic value of ventricular arrhythmias associated with treadmill exercise testing in patients studied with cardiac catheterization for suspected ischemic heart disease. J Am Coll Cardiol 1983;2:1060-1067.

16. Morshedi-Meibodi A, Evans JC, Levy D, et al. Clinical correlates and prognostic significance of exercise-induced ventricular premature beats in the community: the Framingham Heart Study. Circulation 2004;109:2417-2422.

17. Jouven X, Zureik M, Desnos M, et al. Long-term outcome in asymptomatic men with exercise-induced premature ventricular depolarizations. N Engl J Med 2000;343:826-833.

18. Mora S, Redberg RF, Cui Y, et al. Ability of exercise testing to predict cardiovascular and all-cause death in asymptomatic women: a 20-year follow-up of the lipid research clinics prevalence study. JAMA 2003;290:1600-1607.

19. Drory Y, Pines A, Fisman EZ, Kellermann JJ. Persistence of arrhythmia exercise response in healthy young men. Am J Cardiol 1990;66:1092-1094.

20. Morrow K, Morris CK, Froelicher VF, et al. Prediction of cardiovascular death in men undergoing noninvasive evaluation for coronary artery disease. Ann Intern Med 1993;118:689-695.
21. Trejo R, Sierra I, Ferez S, Cardenas M. [Predictive value of ventricular extrasystole in the exertion test and its relation to the magnitude of coronary damage]. Arch Inst Cardiol Mex 1986;56:255-258.

22. Schweikert RA, Pashkow FJ, Snader CE, et al. Association of exercise-induced ventricular ectopic activity with thallium myocardial perfusion and angiographic coronary artery disease in stable, low-risk populations. Am J Cardiol 1999;83:530-4.

23. Rodriguez LM, Waleffe A, Brugada P, et al. Exerciseinduced sustained symptomatic ventricular tachycardia: incidence, clinical, angiographic and electrophysiologic characteristics. Eur Heart J 1990;11:225-232.

24. Gooch AS. Exercise testing for detecting changes in cardiac rhythm and conduction. Am J Cardiol 1972; 30:741-746.

25. Palileo EV, Ashley WW, Swiryn S, et al. Exercise provocable right ventricular outflow tract tachycardia. Eur Heart J 1982;104:185-193.

26. Codini MA, Sommerfeldt L, Eybel CE, Messer JV. Clinical significance and characteristics of exerciseinduced ventricular tachycardia. Cathet Cardiovasc Diagn 1981;7:227-234.

27. Milanes J, Romero M, Hultgren HN, Shettigar U. Exercise tests and ventricular tachycardia. West J Med 1986; 145:473-476.

28. Tamakoshi K, Fukuda E, Tajima A, et al. [Prevalence and clinical background of exercise-induced ventricular tachycardia during exercise testing]. J Cardiol 2002;39:205-212.

29. Biffi A. How to manage athletes with ventricular arrhythmias. Cardiol Clin 2007;25:449-455. 